\title{
OPTIMALISASI DESAIN SISTEM PEMBANGKIT LISTRIK TENAGA HYBRID DIESEL GENERATOR - PHOTOVOLTAIC ARRAY MENGGUNAKAN HOMER (STUDI KASUS : DESA SIRILOGUI, KABUPATEN KEPULAUAN MENTAWAI)
}

\author{
Dewi Purnama Sari ${ }^{1}$, Refdinal Nazir ${ }^{2}$ \\ ${ }^{1}$ Mahasiswa Program Studi S2 Teknik Elektro, Fakultas Teknik, Universitas Andalas \\ ${ }^{2}$ Jurusan Teknik Elektro, Fakultas Teknik, Universitas Andalas \\ e-mail : dpurnamasari88@yahoo.co.id
}

\begin{abstract}
Abstrak-Pembangkit Listrik Tenaga Hybrid merupakan salah satu solusi untuk mengatasi kekurangan pasokan listrik di daerah tertinggal dan terisolir yang tidak terjangkau oleh jaringan listrik PLN, dikarenakan daerah tertinggal pada umumnya memiliki letak geografi dan topografi yang tidak memungkinkan adanya perluasan jaringan listrik PLN. Integrasi dua pembangkit listrik yaitu pembangkit listrik tenaga konvensional (diesel generator) yang bersumber dari bahan bakar minyak (BBM) dengan pembangkit listrik yang bersumber dari energi terbarukan (photovoltaic array) merupakan suatu solusi yang menguntungkan untuk memenuhi kebutuhan beban listrik harian di daerah terpencil seperti Desa Sirilogui yang terletak di Kecamatan Siberut Utara Kabupaten Kepulauan Mentawai, karena dengan integrasi diesel generator-photovoltaic array ini dapat memberikan solusi penerangan 24 jam bagi 310 kepala keluarga (KK) di Desa Sirilogui yang pada mulanya hanya menikmati penerangan selama 4 jam, itupun hanya di malam hari yaitu dari pukul 18.00-22.00 WIB yang bersumber dari 3 unit diesel generator. Dengan adanya integrasi dua pembangkit listrik ini, pengoperasian diesel generator dapat diminimalisir sehingga menghemat pemakaian $\mathrm{BBM}$ dan mengurangi emisi $\mathrm{CO}_{2}$ yang ditimbulkan akibat pengoperasian diesel generator. Penelitian ini memfokuskan pembahasan mengenai Optimalisasi Desain Sistem Pembangkit Listrik Tenaga Hybrid Diesel Generator-Photovoltaic Array dengan menggunakan HOMER sebagai alat bantu simulasinya. HOMER merupakan perangkat lunak yang dipergunakan untuk membantu menyederhanakan tugas modeler dalam mengevaluasi desain sistem pembangkit listrik tenaga hybrid yang memungkinkan dengan mengurutkan berdasarkan pada total net present cost (TNPC) terendah untuk mendapatkan sistem yang paling optimal. Pada penelitian ini, hasil desain untuk sistem dengan beban listrik harian sebesar 479,280 kWh yang paling optimal berdasarkan hasil simulasi menggunakan HOMER yaitu photovoltaic berkapasitas $65 \mathrm{~kW}, 3$ unit diesel generator masing-masing berkapasitas $15 \mathrm{~kW}, 156$ unit battery dan bidirectional converter berkapasitas $78 \mathrm{~kW}$ dengan TNPC sebesar \$1.362.474 dan cost of energy (COE) sebesar 1,485 \$/kWh. Sistem Pembangkit Listrik Tenaga Hybrid Diesel GeneratorPhotovoltaic Array diusulkan dapat mengurangi emisi $\mathrm{CO}_{2}$ 0,06\% per tahun dibandingkan dengan penggunaan diesel generator saja.
\end{abstract}

Kata Kunci:Pembangkit Listrik Tenaga Hybrid, Diesel Generator, Photovoltaic Array, HOMER, Optimalisasi, TNPC

\begin{abstract}
Hybrid Power Plant is one of the solutions to overcome the shortage of electricity in underdeveloped and isolated areas not covered by PLN electricity network, due to underdeveloped regions generally have the geography and topography that does not allow for expansion of PLN electricity network. Integration of the two power plants is a conventional power plant (diesel generator) that comes from fuel oil (BBM) with power plants sourced from renewable energy (photovoltaic arrays) is an advantageous solution to meet the needs of daily electricity load in remote areas such as the Village Sirilogui located in the District of North Siberut Mentawai Islands, because the integration of photovoltaic arrays diesel generator can provide 24 hour lighting solution for 310 households (families) in the village Sirilogui which at first only enjoy the lighting for 4 hours, and even then only at night days, from 06.00 to $10.00 \mathrm{pm}$ o'clock sourced from 3 units of diesel generator. With the integration of these two power plants, diesel generator operation can be minimized so it saves fuel consumption and reduce $\mathrm{CO}_{2}$ emissions caused by the operation of the diesel generator. This study focuses the discussion on Design Optimization of Hybrid Power Plant System Diesel Generator-Photovoltaic Array by using HOMER as a tool for simulation. HOMER software is used to help simplify the task of the modeler in evaluating the design of hybrid power plant system that allows to sort based on the total net present cost (TNPC), the lowest for the most optimal system. In this
\end{abstract}


study, the results of the design for the system with the daily electricity load of 479,280 kWh most optimal based on the simulation results using HOMER ie photovoltaic capacity of $65 \mathrm{~kW}, 3$ units of diesel generators with a capacity of each $15 \mathrm{~kW}, 156$ units of battery and bidirectional converter with a capacity of $78 \mathrm{~kW}$ TNPC amounted to $\$ 1.362 .474$ and the cost of energy (COE) of $\$ 1,485 / \mathrm{kWh}$. Hybrid Power Plant System Diesel Generator-Photovoltaic Array proposed can reduce $\mathrm{CO}_{2}$ emissions by 0,06\% per year compared with the use of diesel generators only.

Keywords: Hybrid Power Plant, Diesel Generator, Photovoltaic Array, HOMER, Optimization, TNPC

\section{PENDAhULUAN}

Sirilogui adalah desa yang berada di Kecamatan Siberut Utara, Kepulauan Mentawai, Propinsi Sumatera Barat, Indonesia. Untuk menempuh perjalanan ke Desa Sirilogui ini harus melewati jalur laut dengan menggunakan kapal NADE ke Sikabaluan kemudian disambung lagi dengan menggunakan kapal boat. Lamanya perjalanan menuju desa ini yaitu selama 11 jam dengan jarak tempuh $150 \mathrm{~km}$. Desa Sirilogui terdiri dari 3 Dusun yaitu Dusun Muara, Dusun Tugu dan Dusun Sitangaik. Secara geografis, Desa Sirilogui terletak antara $1^{\circ} 13^{\prime} 01,8^{\prime \prime} \mathrm{LS}$ dan $99^{\circ} 01^{\prime} 11,1^{\prime \prime} \mathrm{BT}$ dengan luas wilayah desa sekitar $81,87 \mathrm{~km}^{2}$ [1],[2].

Untuk melayani kebutuhan akan penerangan listrik, penduduk Desa Sirilogui mengandalkan diesel generator berukuran $3 \times 15 \mathrm{kVA}$, masing-masing $15 \mathrm{kVA}$ digunakan untuk tiaptiap dusun yang ada di desa ini. Diesel generator ini merupakan bantuan dari PNPM-MP pada tahun 2011[2]. Karena lokasi Desa Sirilogui ini begitu jauh maka ketersediaan bahan bakar solar pun langka, sehingga harganya menjadi sangat mahal. Harga bahan bakar solar yang begitu mahal menyebabkan pengoperasian diesel generator ini hanya digunakan untuk melayani penerangan di malam hari saja yaitu dari pukul 18.00-22.00 WIB dengan beban puncak sebesar $32,125 \mathrm{~kW}$. Apabila supply listrik dari diesel generator terputus, maka tidak ada listrik sama sekali di desa tersebut.

Dampak dari pengoperasian yang tidak efisien ini menyebabkan biaya untuk operasi dan pemeliharaan diesel generator akan menjadi semakin meningkat, terutama biaya bahan bakar minyak (BBM)nya. Oleh karena itu, untuk mengurangi penggunaan BBM pada diesel generator tersebut maka perlu dilakukan perubahan pola operasional diesel generator dari diesel generator tunggal menjadi pembangkit listrik tenaga hybrid agar performance dari diesel generator menjadi optimal.
Karena Desa Sirilogui ini merupakan daerah yang memiliki intensitas cahaya matahari yang cukup tinggi yaitu $\quad 4,8 \mathrm{kWh} / \mathrm{m}^{2} /$ hari[3] sehingga dengan demikian integrasi yang tepat dengan diesel generator untuk dijadikan PLTH adalah photovoltaic array. Dengan pola hunian penduduk yang terpusat di desa ini maka desa ini berpotensi untuk dipasangkan photovoltaic array komunal (terpusat) sebagai pembangkit listrik tambahan yang bersumber dari energi terbarukan.

Pemodelan desain menggunakan perangkat lunak adalah pilihan yang dapat mempermudah modeler dalam menganalisa sistem yang diinginkan. Penelitian ini menggunakan perangkat lunak HOMER sebagai alat bantu simulasi dan untuk mendesain sistem PLTH serta dapat membantu pemilihan desain sistem yang optimal berdasarkan aspek ekonomi, seperti biaya awal, biaya operasional dan perawatan (O\&M) dan biaya bersih sekarang (NPC)[4].

\section{TINJAUAN PUSTAKA}

\subsection{Sistem Pembangkit Listrik Tenaga Hybrid}

Pembangkit listrik tenaga hybrid merupakan integrasi dari dua atau lebih pembangkit listrik dengan sumber energi yang berbeda[5]. Dalam penelitian ini integrasi pembangkit listrik yang dipilih adalah pembangkit listrik konvensional yang berbahan bakar fosil dengan pembangkit listrik berbasis energi terbarukan.

\subsubsection{Konfigurasi Sistem Pembangkit Listrik Tenaga Hybrid \\ Sistem pembangkit listrik tenaga hybrid[6],[7] terbagi atas 3 konfigurasi yaitu:}




\section{A. Sistem Hybrid Seri}

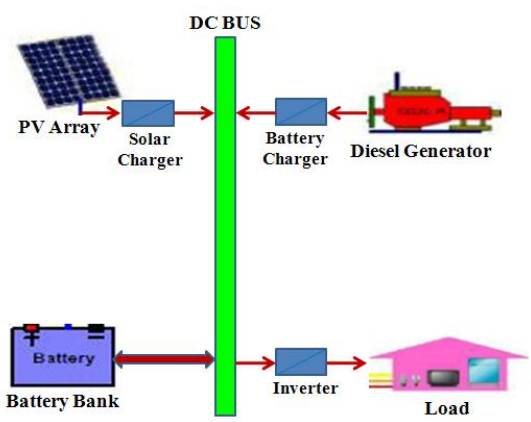

Gambar 1. Pembangkit Listrik Tenaga Hybrid Sistem Seri[6],[7]

\section{B. Sistem Hybrid Switch}

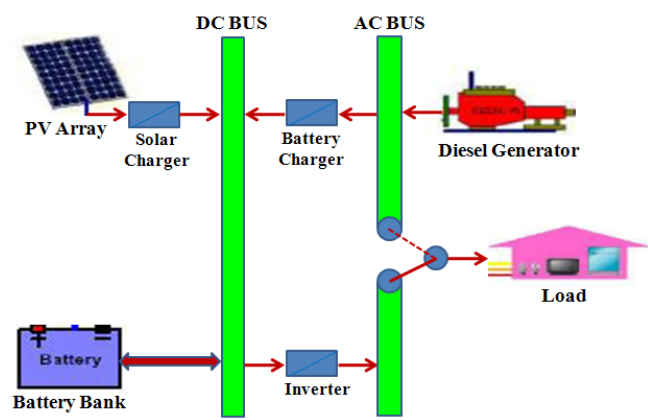

Gambar 2. Pembangkit Listrik Tenaga Hybrid Sistem Switch[6],[7]

\section{Sistem Hybrid Paralel}

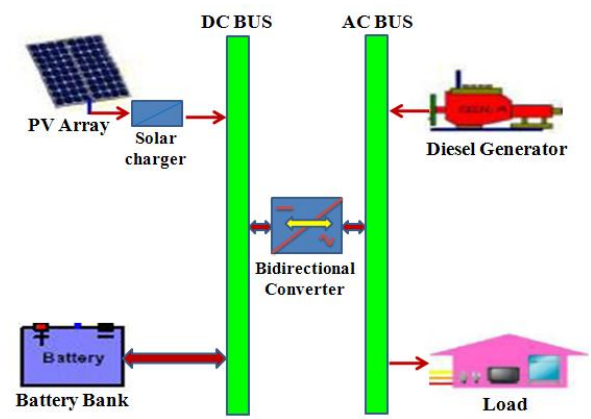

Gambar 3. Pembangkit Listrik Tenaga Hybrid Sistem Paralel[6],[7]

Keuntungan menggunakan konfigurasi sistem pembangkit listrik tenaga hybrid adalah[7],[8]:

1. Beban dapat dipenuhi secara optimal

2. Efisiensi diesel generator tinggi
3. Ukuran diesel generator dan komponen lain dapat diminimalisir sehingga mengurangi biaya investasi

4. Mengurangi ketergantungan terhadap bahan bakar minyak bumi

5. Keandalan dan efisiensi sistem akan meningkat

6. Meningkatkan waktu layanan listrik secara ekonomis

7. Mengurangi emisi dan polusi

8. Meningkatkan umur operasi sistem

9. Biaya operasional dan maintenance relatif murah

10. Biaya produksi energi listrik atau Cost of Energy $(\mathrm{Rp} / \mathrm{kWh})$ per tahun relatif murah.

\subsection{Komponen-komponen Pendukung Sistem Pembangkit Listrik Tenaga Hybrid Diesel Generator-Photovoltaic Array}

\section{A. Diesel Generator}

Diesel generator adalah suatu pembangkit listrik yang terdiri dari kombinasi mesin diesel dengan generator listrik (alternator) yang berfungsi untuk menghasilkan energi listrik. Diesel generator biasanya digunakan untuk memenuhi kebutuhan listrik dengan pemakaian beban dalam jumlah kecil atau dapat berfungsi sebagai backup apabila pembangkit listrik utama tidak mampu melayani supply daya ke beban dan sebagai cadangan untuk melayani beban di waktu puncak pemakaian tenaga listrik oleh konsumen.

Diesel generator juga merupakan salah satu pembangkit listrik yang menjadi solusi untuk melayani supply daya listrik di daerah tertinggal dan terisolir yang tidak mendapat jangkauan listrik.

\section{B. Photovoltaic Array}

Photovoltaic array merupakan suatu teknologi pembangkit listrik yang mengkonversikan energi foton dari surya menjadi energi listrik[9],[10]. Proses konversi ini terjadi pada modul surya yang terdiri dari selsel surya. Berdasarkan teknologi pembuatannya, sel surya dapat dibagi dalam tiga jenis, yaitu[11]:

a. Monocrystalline Solar Cell

b. Polycrystalline Solar Cell

c. Thin Film Solar Cell (TFSC)

Dalam penelitian ini, jenis modul surya yang digunakan adalah monocrystalline solar cell. 
Monocrystalline solar cell dipilih karena memiliki efisiensi paling tinggi dibandingkan dengan jenis sel surya lainnya, sekitar 15\%-20\%. Tenaga listrik yang dihasilkan oleh satu sel surya sangat kecil sehingga beberapa sel surya harus digabungkan untuk membentuk suatu modul surya.

Berikut ini merupakan susunan sel surya hingga membentuk suatu array.

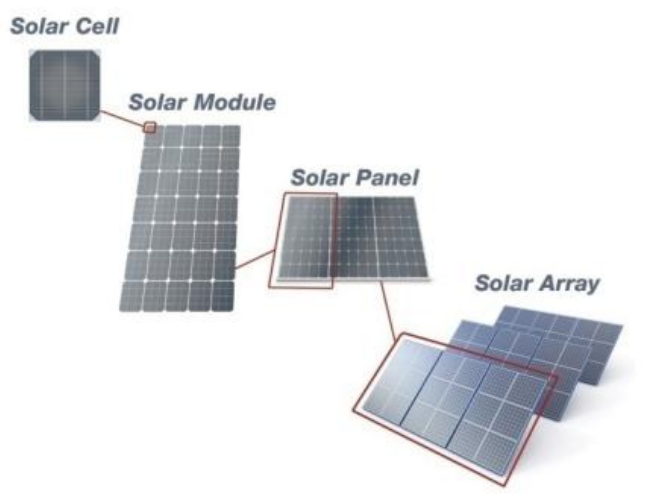

Gambar 4. Diagram hubungan sel surya, modul, panel, array[12]

Beberapa faktor yang mempengaruhi pengoperasian maksimum modul surya yaitu[13]:

1. Temperatur

2. Intensitas Cahaya Matahari

3. Orientasi Rangkaian Modul Surya

4. Sudut Orientasi Matahari (tilt angle)

Untuk penentuan besar kapasitas terpasang yang dibangkitkan oleh photovoltaic array maka digunakan persamaan-persamaan berikut ini:

a. Luas area photovoltaic array

$$
\text { Area array }=\frac{\mathrm{E}_{\mathrm{L}}}{\mathrm{G}_{\mathrm{av}} \cdot \eta_{\mathrm{PV}} \cdot \mathrm{TCF} \cdot \eta_{\text {output }}}
$$

b. Daya yang di bangkitkan photovoltaic array

$\mathrm{P}$ Watt peak $=$ Area array $\cdot \mathrm{PSI} \cdot \eta_{\mathrm{PV}}$

c. Jumlah modul surya yang dibutuhkan

$$
\text { Jumlah modul surya }=\frac{\mathrm{P}_{\text {Watt peak }}}{\mathrm{P}_{\text {MPP }}}
$$

\section{Dimana:}

$\begin{aligned} \mathrm{E}_{\mathrm{L}} & =\text { pemakaian energi }(\mathrm{kWh} / \text { hari) } \\ \mathrm{Gav} & =\text { insolasi harian rata-rata } \\ & \text { matahari }\left(\mathrm{kWh} / \mathrm{m}^{2} / \text { hari }\right) \\ \eta_{\mathrm{PV}} & =\text { efisiensi modul surya }(\%)\end{aligned}$

$$
\begin{aligned}
\mathrm{TCF} & =\text { temperature correction factor } \\
\eta_{\text {out } \mathrm{put}}= & \text { efisiensi output dari modul } \\
& \text { surya }(\%) \\
\mathrm{PSI} & \text { peak solar insolation adalah } \\
& 1000 \mathrm{~W} / \mathrm{m}^{2} \\
\mathrm{P}_{\mathrm{Watt} \text { Peak }}= & \text { daya yang dibangkitkan }(\mathrm{Wp}) \\
\mathrm{P}_{\mathrm{MPP}}= & \text { daya maksimum modul surya } \\
& (\mathrm{W})
\end{aligned}
$$

\section{Battery Bank}

Battery (aki) adalah sebagai penyimpan energi listrik yang diisi oleh aliran DC dari modul photovoltaic. Ukuran kapasitas battery dinyatakan dengan satuan Ampere-hours (Ah)[13]. Pada penelitian ini, jenis rechargeable battery yang digunakan adalah lead acid battery. Battery dalam penggunaannya sebagai sumber pembangkit tenaga listrik biasanya hanya sekitar 20\%-30\%. Hal ini dikarenakan battery merupakan sumber pembangkit tenaga listik yang tidak bisa dipakai selama 24 jam karena harus mengalami fase charging dan discharging[13],[14],[15].

Kapasitas (Ah) dari suatu battery dapat dihitung dengan menggunakan persamaan berikut:

- Jumlah battery

Jumlah battery $=\frac{\mathrm{V}_{\text {sistem }}}{\mathrm{V}_{\text {battery }}}$

- Kapasitas battery

$$
\mathrm{Ah}=\frac{\mathrm{E}_{\mathrm{AC}}}{\mathrm{V}_{\text {sistem }}}
$$

- Kapasitas battery yang melibatkan efisiensi kerja inverter

Ah dg. efisiensi kerja inverter

$=$ Kap. batt $+[(100 \%-$ Eff. inv $) \cdot$ Kap. batt $]$

(6)

- Kapasitas minimal battery yang dibutuhkan

$$
\mathrm{Ah}_{\text {min. }}=\frac{\text { Ah dg.efisiensi kerja inverter } \mathrm{t}_{\text {otonomi }}}{\text { \% DOD }}(7)
$$

Dimana:

$$
\begin{aligned}
& \mathrm{E}_{\mathrm{AC}} \quad=\text { kebutuhan energi listrik } \\
& \text { konsumen (Wh) } \\
& \mathrm{V}_{\text {sistem }}=\text { tegangan } \operatorname{sistem}(\mathrm{V}) \\
& \mathrm{V}_{\text {battery }} \quad=\text { tegangan nominal } \operatorname{battery}(\mathrm{V}) \\
& \mathrm{Ah} \quad=\text { kapasitas battery (Ampere hour) }
\end{aligned}
$$




\author{
$\% \mathrm{DOD}=$ persentase tingkat kedalaman \\ discharge maksimum yang dapat \\ diberlakukan pada battery \\ $\mathrm{t}_{\text {otonomi }}=$ suatu kondisi hari dimana jumlah \\ hari yang diasumsikan terjadi \\ hujan/mendung/tidak ada sinar \\ matahari selama 3 hari berturut- \\ turut[15].
}

\section{Bidirectional Converter}

Bidirectional converter merupakan suatu alat yang digunakan untuk mengkonversi sumber listrik DC 12, 24, 48 Volt yang dihasilkan dari sumber listrik seperti photovoltaic module dan battery, menjadi sumber listrik AC (inverter) yang dapat dimanfaatkan sesuai spesifikasi peralatan elektrik (120 atau $240 \mathrm{~V}$ AC, 50 atau $60 \mathrm{~Hz}$ ) atau setara dengan listrik PLN dan sebaliknya (rectifier)[14].

Dalam pemilihan bidirectional converter (inverter) sebaiknya kapasitas kerja yang dipilih mendekati kapasitas daya yang dilayani, dengan tujuan agar efisiensi kerja bidirectional converter (inverter) menjadi maksimal[14]. Adapun ketentuan rating bidirectional converter (inverter) yang digunakan dalam melayani supply daya ke beban dari suatu sistem pembangkit tenaga listrik yaitu adanya penambahan sekitar 20\%-25\% dari kapasitas daya yang akan dilayani[14].

Pada umumnya efisiensi bidirectional converter (inverter) adalah berkisar 50\%-90\% tergantung dari tipe bidirectional converter (inverter) dan beban outputnya. Bila beban outputnya semakin mendekati beban kerja bidirectional converter (inverter) yang tertera maka efisiensinya semakin besar, demikian pula sebaliknya[15].

\subsection{HOMER}

HOMER merupakan sebuah perangkat lunak yang dikembangkan oleh NREL yang digunakan untuk mendesain sistem pembangkit listrik tenaga hybrid menggunakan energi terbarukan[16]. HOMER merupakan suatu program simulasi yang mengoptimalkan sistem pembangkit listrik baik stand alone (off grid) maupun grid connected yang dapat terdiri dari kombinasi pembangkit listrik konvensional dan kombinasi pembangkit sumber energi terbarukan, battery bank, bidirectional converter serta untuk melayani beban listrik maupun thermal[17]. HOMER juga berfungsi untuk mempermudah modeler dalam merancang dan menganalisa berbagai macam aplikasi sistem tenaga listrik, baik yang terhubung ke grid maupun tidak. HOMER mengizinkan pengguna untuk membandingkan beberapa rancangan sistem yang berbeda berdasarkan faktor sumber daya alam, ekonomi (biaya) dan komponen peralatan yang digunakan[17].

\section{METODOLOGI PENELITIAN}

Dalam penelitian ini didesain sebuah sistem Pembangkit Listrik Tenaga Hybrid Diesel Generator-Photovoltaic Array dengan model kombinasi sistem paralel-switch.

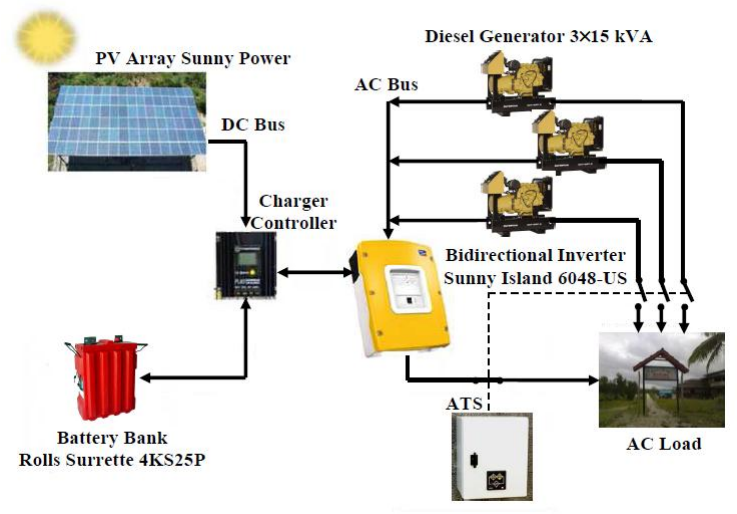

Gambar 5. Sistem Hybrid Paralel-Switch Diesel Generator-Photovoltaic Array

Adapun kerja sistem PLTH Diesel GeneratorPhotovoltaic Array adalah sebagai berikut:

- $\mathrm{P}_{\text {Beban }}<\mathrm{P}_{\mathrm{PV} \text { Array }} \rightarrow 100 \%$ PV Array

- $\mathrm{P}_{\text {Beban }}>\mathrm{P}_{\mathrm{PV} \text { Array }} \rightarrow \mathrm{PV}$ Array + Battery Bank

- $\mathrm{P}_{\text {Beban }}<\mathrm{P}_{\mathrm{PV} \text { Array }} \& \mathrm{P}_{\text {Battery Bank }} \rightarrow \mathrm{PV}$ Array + Battery Bank (full condition)

- $\mathrm{P}_{\text {Beban }}>75 \%$ dari $\mathrm{P}_{\mathrm{PV} \text { Array }} \& \mathrm{P}_{\text {Battery Bank }}$ (Min. SOC Batt. Bank $\leq 40 \%)<$ dari $\mathrm{P}_{\text {Diesel Generator }}$ $\rightarrow$ Diesel Generator

- $\mathrm{P}_{\text {Beban Puncak }}<\mathrm{P}_{\text {Diesel Generator }} \rightarrow$ Diesel Generator

- $\mathrm{P}_{\text {Beban Puncak }}>\mathrm{P}_{\text {Diesel Generator }} \rightarrow$ Diesel Generator + Battery Bank 
Sistem didesain dengan model pembagian bebannya sebagai berikut dengan model profil beban berikut ini.

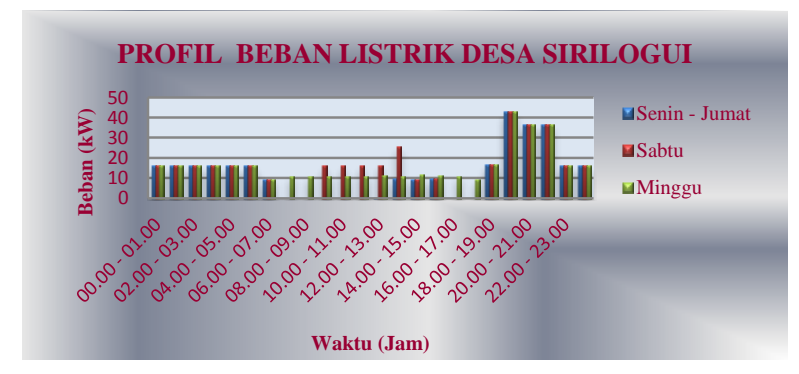

Gambar 6. Grafik Estimasi Profil Beban Listrik Desa Sirilogui

Ada 2 skenario desain sistem PLTH Diesel Generator-Photovoltaic Array yang akan dirancang dalam penelitian ini.

I. Desain sistem PLTH 3 unit diesel generatorphotovoltaic array

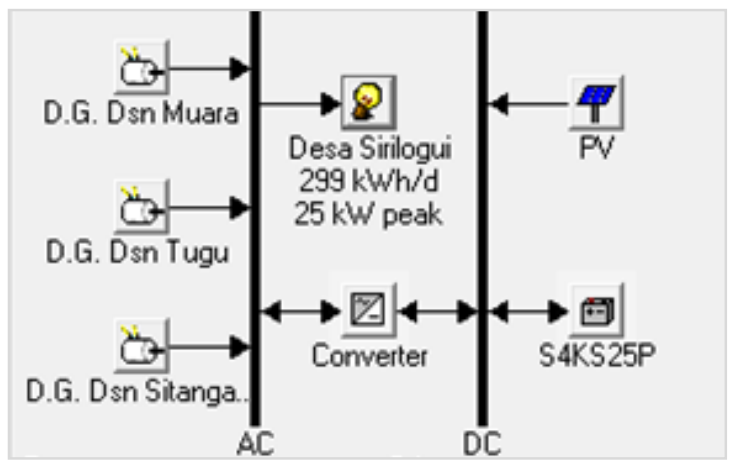

Gambar 7. Desain Sistem Pembangkit Listrik Tenaga Hybrid 3 Diesel

Generator-Photovoltaic Array

Model sistem pembagian bebannya yaitu:

Kondisi Normal

Kondisi I

- Dari pukul 06.00-18.00 WIB, beban listrik Desa Sirilogui dilayani oleh photovoltaic array

- Dari pukul 18.00-21.00 WIB, beban listrik Desa Sirilogui dilayani oleh diesel generator

- Dari pukul 21.00-06.00 WIB, beban listrik Desa Sirilogui dilayani oleh battery bank.

Kondisi Tidak Normal

\section{Kondisi II}

- Dari pukul 06.00-18.00 WIB, beban listrik Desa Sirilogui dilayani oleh photovoltaic array dan battery bank dari pukul 06.0007.00 WIB dan 13.00-16.00 WIB

- Dari pukul 18.00-06.00 WIB, beban listrik Desa Sirilogui dilayani oleh diesel generator dan battery bank dari pukul 21.00-6.00 WIB.

Kondisi III (Khusus Weekend)

- Dari pukul 06.00-18.00 WIB, beban listrik Desa Sirilogui dilayani oleh photovoltaic array dan diesel generator beroperasi dari pukul 07.00-17.00 WIB

- Dari pukul 18.00-21.00 WIB, beban listrik Desa Sirilogui dilayani oleh diesel generator

- Dari pukul 21.00-06.00 WIB, beban listrik Desa Sirilogui dilayani oleh battery bank.

II. Desain sistem PLTH 5 unit diesel generatorphotovoltaic array

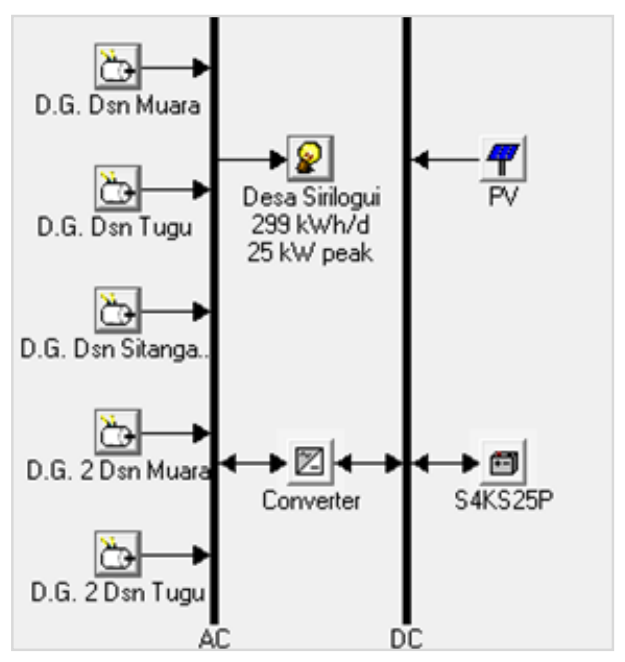

Gambar 8. Desain Sistem Pembangkit Listrik Tenaga Hybrid 5 Diesel

Generator-Photovoltaic Array

Model sistem pembagian bebannya yaitu:

Kondisi I

- Dari pukul 06.00-18.00 WIB, beban listrik Desa Sirilogui dilayani oleh photovoltaic array dan battery bank. Pada kondisi ini battery bank hanya digunakan pada siang 
hari yaitu sebagai backup saat terjadi beban puncak di siang hari.

- Dari pukul 18.00-21.00 WIB, beban listrik Desa Sirilogui dilayani oleh diesel generator 1

- Dari pukul 21.00-06.00 WIB, beban listrik Desa Sirilogui dilayani oleh diesel generator 2

\section{Kondisi II (Khusus Weekend)}

- Dari pukul 06.00-18.00 WIB, beban listrik Desa Sirilogui dilayani oleh photovoltaic array dan battery bank serta ditambah dengan pengoperasian 3 unit diesel generator 1 dari pukul 07.00-17.00 WIB

- Dari pukul 18.00-21.00 WIB, beban listrik Desa Sirilogui dilayani oleh 3 unit diesel generator 1

- Dari pukul 21.00-06.00 WIB, beban listrik Desa Sirilogui dilayani oleh 2 unit diesel generator 2.

Dalam mendesain sistem PLTH Diesel Generator-PV Array ini dibutuhkan data-data komponen sebagai berikut:

\section{- Diesel Generator}

Diesel generator yang digunakan adalah merk Olympian tipe GEP16SP-2 dengan kapasitas daya sebesar $15 \mathrm{~kW}$ [18].

Berikut ini merupakan spesifikasi teknik dari diesel generator Olympian tipe GEP16SP-2

Tabel 1. Spesifikasi Teknik Diesel Generator Olympian GEP16SP-2[18]

\begin{tabular}{|l|c|}
\hline \multicolumn{1}{|c|}{ Spesifikasi Teknik } & Keterangan \\
\hline Model & $220-240 \mathrm{~V}$ \\
\hline Prime & $15 \mathrm{~kW}$ \\
\hline Standby & $16,5 \mathrm{~kW}$ \\
\hline Frequency & $50 \mathrm{~Hz}$ \\
\hline Fuel Tank Capacity & 45 litres \\
\hline Fuel Consumption, Prime & 5,1 litres hours \\
\hline Fuel Consumption, Standby & 5,8 litres hours \\
\hline
\end{tabular}

\section{- Photovoltaic Array}

Modul surya yang digunakan adalah jenis silicon monocrystalline merk Sunny Power dengan kapasitas $100 \mathrm{Wp}[19]$.

Berikut ini merupakan spesifikasi teknik dari modul surya jenis silicon monocrystalline merk Sunny Power.
Tabel 2. Spesifikasi Teknik Modul Surya Silicon Monocrystalline Sunny Power[19]

\begin{tabular}{|l|c|}
\hline \multicolumn{1}{|c|}{ Spesifikasi Teknik } & Keterangan \\
\hline Maximum power $\left(\mathrm{P}_{\mathrm{m}}\right)$ & $100 \mathrm{~W}$ \\
\hline Power measurement tolerance & $\pm 5 \%$ \\
\hline Nominal voltage & $12 \mathrm{~V} \mathrm{DC}$ \\
\hline Voltage at max power $\left(\mathrm{V}_{\mathrm{mp}}\right)$ & $17,4 \mathrm{~V}$ \\
\hline Current at max power $\left(\mathrm{I}_{\mathrm{mp}}\right)$ & $5,75 \mathrm{~A}$ \\
\hline Short circuit current $\left(\mathrm{I}_{\mathrm{sc}} \mathrm{c}\right.$ & $6,33 \mathrm{~A}$ \\
\hline Open circuit voltage $\left(\mathrm{V}_{\mathrm{oc}}\right)$ & $21,6 \mathrm{~V}$ \\
\hline Operating temperature & $-40^{\circ} \mathrm{C}$ to $+85^{\circ} \mathrm{C}$ \\
\hline Maximum system voltage & $1000 \mathrm{~V}$ \\
\hline Maximum series fuse rating & $8 \mathrm{~A}$ \\
\hline Number of cells and connections & $36=4 \times 9$ pcs \\
\hline Solar cell (mm) & $125 \times 125$ \\
\hline Dimension of module $(\mathrm{mm})$ & $1200 \times 540 \times 30$ \\
\hline Standard Test Condition $(\mathrm{STC})$ & Irradiance $1000 \mathrm{~W} / \mathrm{m}^{2}, \mathrm{Modul}$ te temperature $25^{\circ} \mathrm{C}, \mathrm{AM}=1,5$ \\
\hline Weight & $8,5 \mathrm{~kg}$ \\
\hline NOCT & $48^{\circ} \mathrm{C} \pm 2^{\circ} \mathrm{C}$ \\
\hline Power temperature coefficient & $-(0,5 \pm 0,05) \% \mathrm{~K}$ \\
\hline
\end{tabular}

\section{- Battery}

Jenis battery yang digunakan adalah battery deep cycle merk Rolls Surrette tipe 4KS25P dengan kapasitas nominal $1.900 \mathrm{Ah}(7,6 \mathrm{kWh})$ dan tegangan nominal $4 \mathrm{~V}$ dengan masa usia teknis maksimal 15 tahun[20].

Berikut ini merupakan spesifikasi teknik dari battery Rolls Surrette 4KS25P

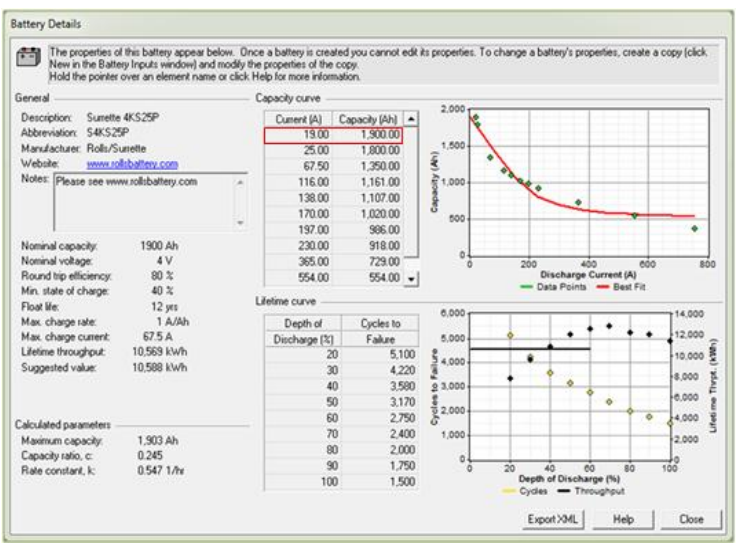

Gambar 9. Karakteristik Battery Rolls Surrette $4 \mathrm{KS} 25 \mathrm{P}$

- Bidirectional Converter

Converter yang digunakan adalah bidirectional converter (inverter-rectifier) 1 phasa kapasitas $6000 \mathrm{~W}$ merk Sunny Island tipe 6048-US produksi SMA America, LLC[21].

Berikut ini merupakan spesifikasi teknik dari bidirectional converter Sunny Island 6048-US 
Tabel 3. Spesifikasi Teknik Bidirectional

Converter Sunny Island 6048-US[21]

\begin{tabular}{|l|c|}
\hline \multicolumn{1}{|c|}{ Technical Data } & Keterangan \\
\hline Maximum DC power & $6,7 \mathrm{~kW}$ \\
\hline Maximum DC voltage & $120 \mathrm{~V}$ \\
\hline Nominal AC range & $105-132 \mathrm{~V}$ \\
\hline Frequency adjustable & $55-65 \mathrm{~Hz}$ \\
\hline Rated current & $48 \mathrm{~A}$ \\
\hline Maximum output AC power & $6000 \mathrm{~W}$ \\
\hline Power factor & -1 to +1 \\
\hline Maximum efficiency & $96 \%$ \\
\hline Dimension (W / H / D) & $467 / 612 / 235 \mathrm{~mm}$ \\
\hline Weight & $63 \mathrm{~kg}$ \\
\hline
\end{tabular}

Adapun tahapan-tahapan yang dilakukan dalam pemilihan desain yang optimal dari Sistem PLTH Diesel Generator-Photovoltaic Array ini dapat dilihat pada diagram alir penelitian berikut ini.

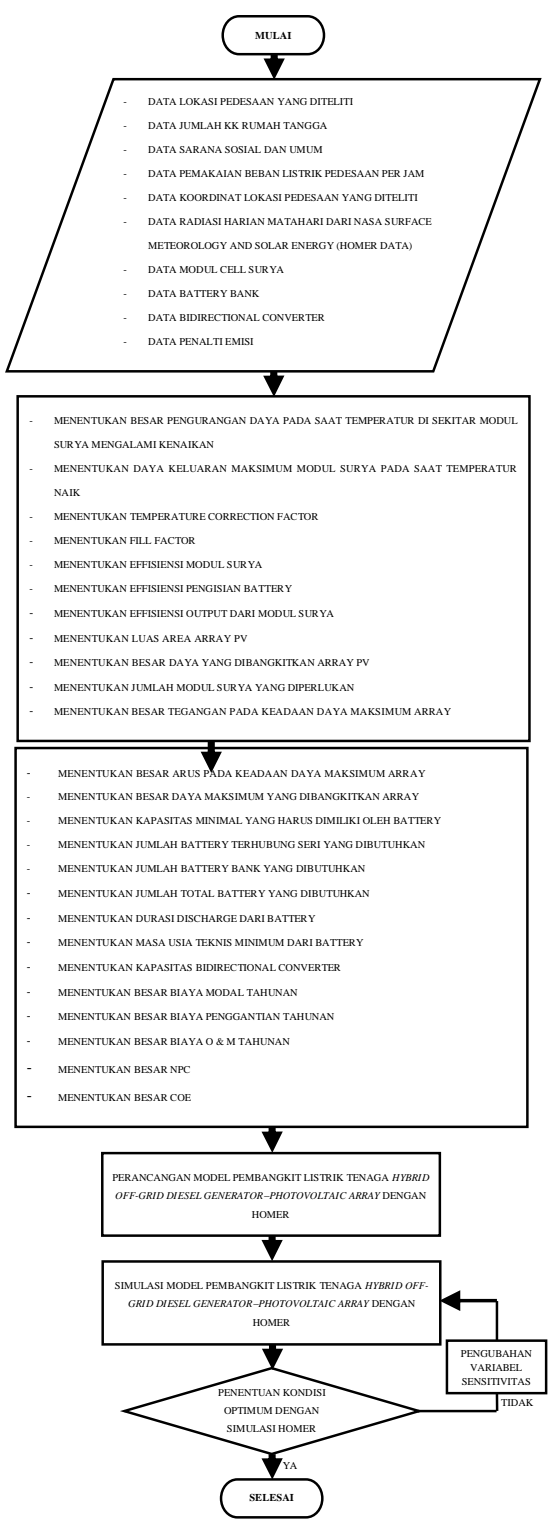

Gambar 10. Diagram Alir Penelitian

\section{HASIL DAN PEMBAHASAN}

Dari hasil simulasi dengan mempergunakan perangkat lunak HOMER maka diperoleh optimization results dari 2 desain sistem PLTH diesel generator-photovoltaic array sebagai berikut.

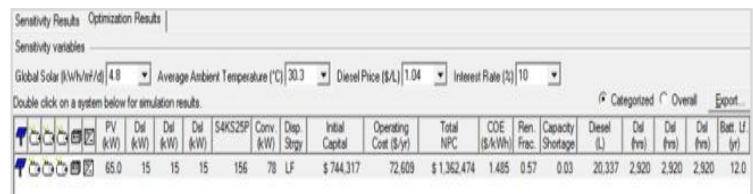

Gambar 11. Optimization Results dari Desain Sistem Pembangkit Listrik Tenaga Hybrid 3 Diesel Generator-Photovoltaic Array

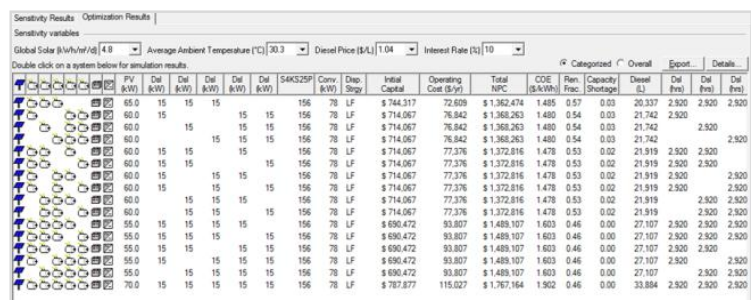

Gambar 12. Optimization Results dari Desain Sistem Pembangkit Listrik Tenaga Hybrid 3 Diesel Generator-Photovoltaic Array

Hasil optimalisasi dari 2 skenario desain sistem PLTH diesel generator-photovoltaic array apabila diurutkan berdasarkan NPC terendah dan COE maka diperoleh beberapa desain sistem yang optimal seperti yang terlihat pada grafik berikut ini.

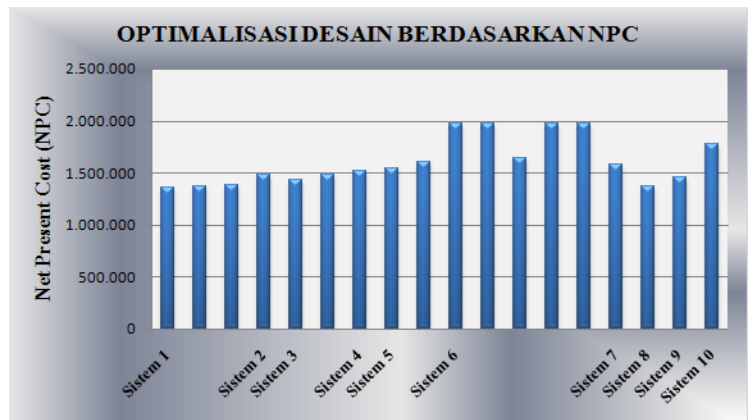

Gambar 13. Grafik Optimalisasi Desain Sistem Pembangkit Listrik Tenaga Hybrid 3 Diesel Generator-Photovoltaic Array Berdasarkan NPC 


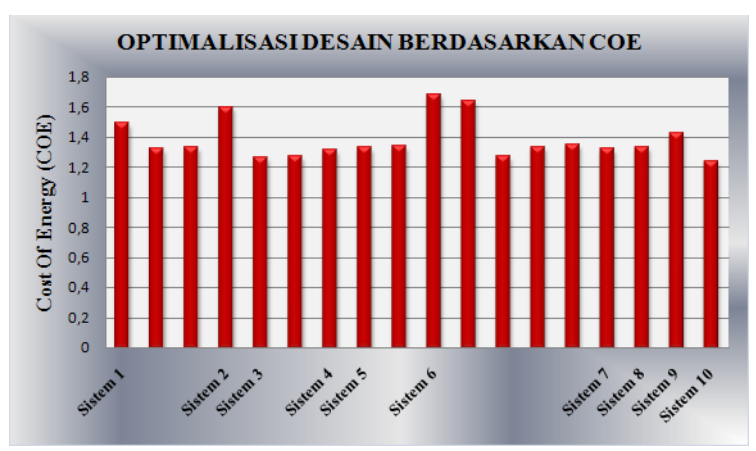

Gambar 14. Grafik Optimalisasi Desain Sistem Pembangkit Listrik Tenaga Hybrid 3 Diesel Generator-Photovoltaic Array Berdasarkan COE

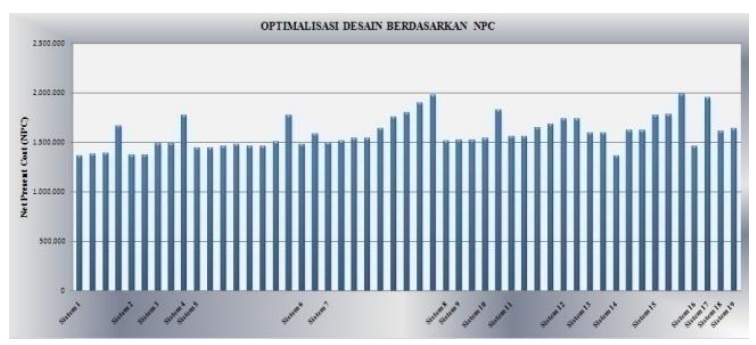

Gambar 15. Grafik Optimalisasi Desain Sistem Pembangkit Listrik Tenaga Hybrid 5 Diesel Generator-Photovoltaic Array Berdasarkan NPC

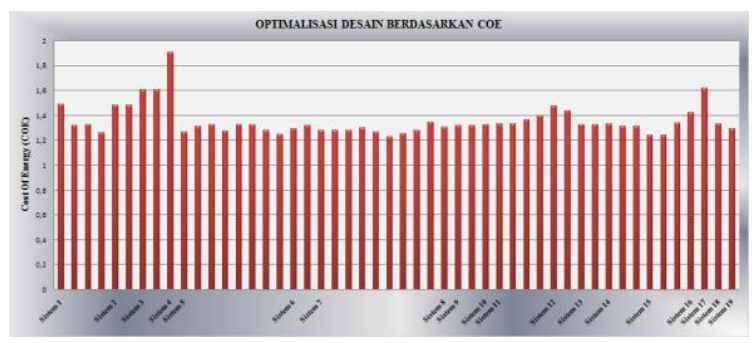

Gambar 16. Grafik Optimalisasi Desain Sistem Pembangkit Listrik Tenaga Hybrid 5 Diesel Generator-Photovoltaic Array Berdasarkan $\mathrm{COE}$

Dari beberapa desain sistem tersebut, berdasarkan hasil simulasi menggunakan HOMER maka dipilih desain sistem yang paling optimal dari beberapa pilihan desain sistem yang optimal yaitu desain sistem dengan total net present cost terendah sebesar $\$ 1.362 .474$ dimana desain sistemnya terdiri dari photovoltaic array $65 \mathrm{~kW}, 3$ unit diesel generator masing-masing berkapasitas $15 \mathrm{~kW}$, battery 156 unit dan bidirectional converter 78
$\mathrm{kW}$ dengan strategi dispatchnya yaitu load following dimana untuk simulasinya membutuhkan waktu selama 12 menit 35 detik.

Pada desain sistem Pembangkit Listrik

Tenaga Hybrid Diesel Generator-Photovoltaic Array ini, HOMER melakukan sebanyak 1728 simulasi dan 360 sensitivitas dari 4 variabel sensitivitas yaitu: global solar, average ambient temperature, diesel price dan interest rate.

Berikut ini merupakan penjabaran hasil simulasi desain sistem yang paling optimal dari Pembangkit Listrik Tenaga Hybrid Diesel Generator-Photovoltaic Array dengan mempergunakan HOMER.

\section{- Sensitivity results}

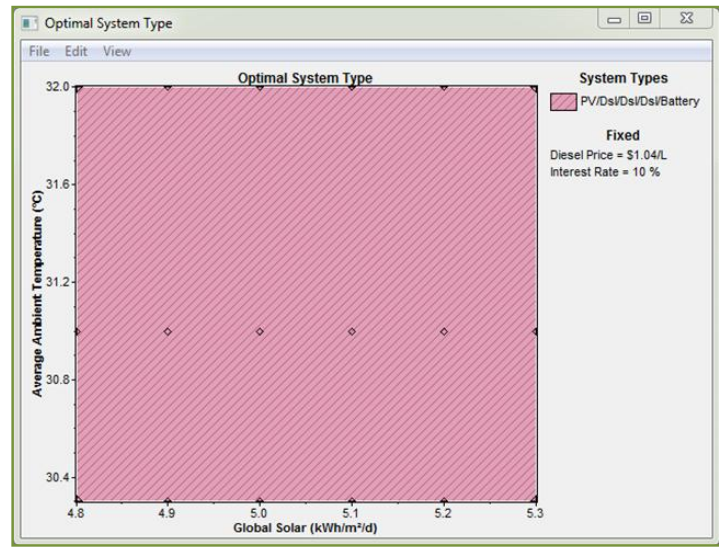

Gambar 17. Sensitivity Results dari Optimal System Type

Pada sensitivity results, faktor yang paling berpengaruh adalah global solar $\left(\mathrm{kWh} / \mathrm{m}^{2} / \mathrm{d}\right)$ dan temperatur ambient rata-rata $\left({ }^{\circ} \mathrm{C}\right)$. Berdasarkan grafik tersebut diketahui bahwa tipe sistem yang paling optimal dipilihkan HOMER yaitu:

- Sistem hybrid photovoltaic array-3 unit diesel generator-battery, dimana sistem ini dipilihkan HOMER sebagai sistem yang paling optimal dengan posisi global solar berada di kisaran $4,80 \mathrm{kWh} / \mathrm{m}^{2} / \mathrm{d}-\quad 5,3$ $\mathrm{kWh} / \mathrm{m}^{2} / \mathrm{d}$ dengan temperatur ambient ratarata berada di rentang $30,3^{\circ} \mathrm{C}-32^{\circ} \mathrm{C}$

- Warna yang tampil pada grafik menunjukkan pilihan sistem yang paling optimal berdasarkan total net present cost terendah yang dipilihkan HOMER. Apabila harga bahan bakar diesel dan tingkat suku bunga dinaikkan hingga mencapai nilai maksimum 
yang ditetapkan, tidak akan mempengaruhi sistem hybrid tersebut tetapi sebaliknya berpengaruh terhadap perubahan total net present cost, cost of energy dan operating cost.

- Hasil simulasi sistem ditinjau dari cost summary

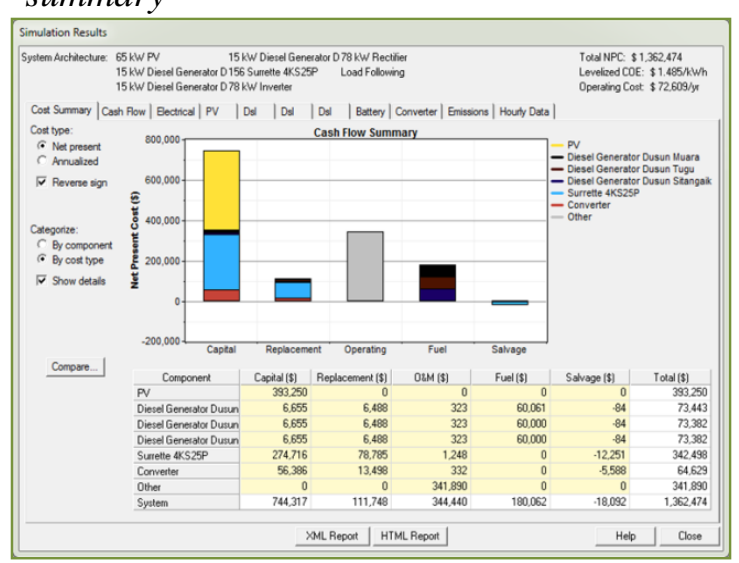

Gambar 18. Hasil Simulasi Berdasarkan NPC

Pada gambar terlihat bahwa biaya terbesar yang harus dikeluarkan selama 20 tahun atau selama proyek berlangsung adalah biaya investasi awal yaitu sebesar \$ 744.317 atau $54,63 \%$ dari total NPC, kemudian diikuti dengan biaya operasional dan pemeliharaan sebesar \$ 344.440 atau $25,28 \%$, biaya bahan bakar sebesar $\$ 180.062$ atau $13,22 \%$ dan biaya penggantian komponen sebesar

111.748 atau $8,20 \%$.

- Hasil simulasi sistem ditinjau dari electrical

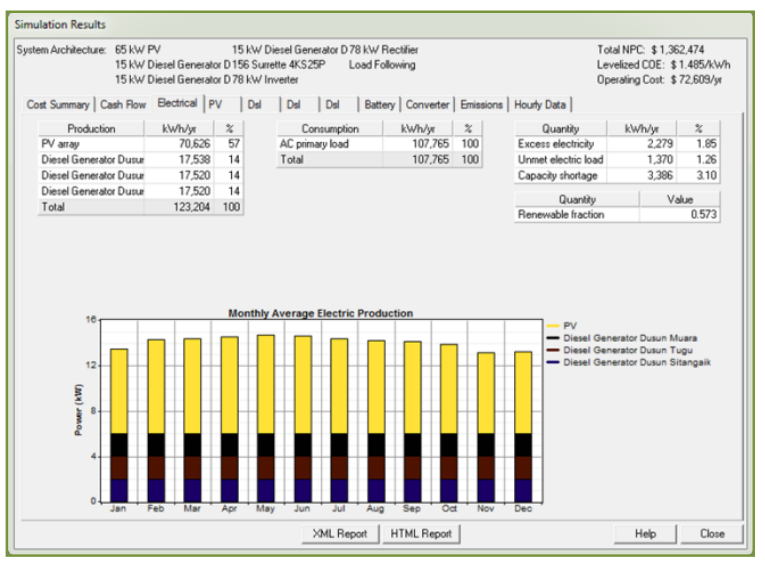

Gambar 19. Hasil Simulasi Electrical
Berdasarkan hasil simulasi terlihat bahwa produksi energi listrik yang dihasilkan oleh sistem Pembangkit Listrik Tenaga Hybrid Diesel Generator-Photovoltaic Array per tahunnya sebesar $123.204 \mathrm{kWh}$ dimana produksi energi listrik terbesar berasal dari photovoltaic array dengan renewable fraction sebesar 0,573 dan kelebihan listrik sebesar $2.279 \mathrm{kWh} /$ tahun. Walaupun sistem hybrid ini mampu untuk melayani pemakaian beban listrik secara keseluruhan akan tetapi sistem tersebut masih memiliki capacity shortage sebesar 3,10\% atau sekitar $3.386 \mathrm{kWh} /$ tahun dimana ini terlihat dengan masih belum terpenuhinya beban listrik sebesar $\quad 1.370$ $\mathrm{kWh} /$ tahun sedangkan konsumsi energi listrik per tahunnya sebesar $107.765 \mathrm{kWh}$. Pada gambar di atas terlihat bahwa produksi listrik rata-rata per bulan yang tertinggi terjadi di bulan Mei.

- Hasil simulasi ditinjau dari emisi

Tabel 4. Besar Emisi Yang Dihasilkan

\begin{tabular}{|l|r|}
\hline \multicolumn{1}{|c|}{ Pollutant } & Emissions $[\mathrm{kg} / \mathrm{yr}]$ \\
\hline Carbon dioxide & 52,308 \\
\hline Carbon monoxide & 779 \\
\hline Unburned hydrocarbons & 86.2 \\
\hline Particulate matter & 58.8 \\
\hline Sulfur dioxide & 75.3 \\
\hline Nitrogen oxides & 6.955 \\
\hline
\end{tabular}

- Output sistem hybrid diesel generatorphotovoltaic array

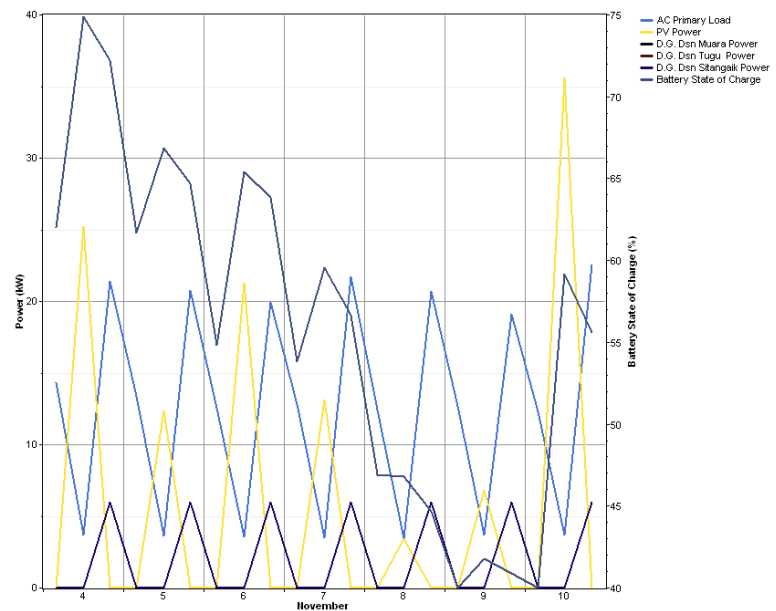

Gambar 20. Output Sistem Hybrid Diesel Generator-Photovoltaic Array 
Gambar di atas menunjukkan hasil simulasi gabungan komponen per jam dalam satu hari selama bulan November. Bulan November dipilih karena intensitas radiasi matahari pada bulan ini adalah yang terendah dari bulan-bulan yang lain. Seperti yang terlihat pada gambar dimana tanggal 8 November intensitas radiasi matahari lebih rendah dari beban listrik AC sehingga beban listrik AC disupply oleh battery yang dicharge oleh photovoltaic.

\section{KESIMPULAN}

Setelah dilakukan simulasi menggunakan perangkat lunak HOMER 2 versi 2.81 untuk mendapatkan Optimalisasi Desain dan Analisis Ekonomi Teknik Sistem Pembangkit Listrik Tenaga Hybrid Diesel Generator-Photovoltaic Array, maka dapat ditarik beberapa kesimpulan sebagai berikut.

1. Dari penelitian ini diperoleh suatu desain sistem Pembangkit Listrik Tenaga Hybrid Diesel Generator-Photovoltaic Array yang paling optimal berdasarkan pada total NPC terendah dimana desain sistem Pembangkit Listrik Tenaga Hybrid ini terdiri dari 3 unit diesel generator berkapasitas masing-masing $15 \mathrm{~kW}$, photovoltaic array berkapasitas 65 $\mathrm{kW}$ dengan jumlah modul sebanyak 648 modul (162 string dari 4 modul yang terhubung seri), battery berjumlah 156 unit (13 bank battery terhubung paralel dari 12 unit battery yang terhubung seri) dengan kapasitas sebesar 23.678 Ah dan bidirectional converter yang berkapasitas 78 $\mathrm{kW}$ terdiri dari 13 unit.

2. Ditinjau dari segi ekonomi, apabila semakin besar proporsi energi terbarukan yang digunakan, maka initial capital atau biaya awal yang dihasilkan juga akan semakin besar. Namun dengan semakin besarnya kapasitas energi terbarukan yang terpasang, akan menurunkan tingkat penggunaan bahan bakar dan biaya yang dikeluarkan untuk bahan bakar. Dan dengan berkurangnya biaya yang dikeluarkan untuk bahan bakar, semakin berkurang juga total net present cost yang dihasilkan mengingat bahan bakar menjadi salah satu aspek terbesar dalam hal pengeluaran biaya.

\section{DAFTAR PUSTAKA}

[1] PT. PLN (Persero) Wilayah Sumatera Barat. (2013, September 7). Road Map Lisdes Wilayah Sumatera Barat 2012-2017. [Online]. Available: http://www.pln.co.id/sumbar

[2] (2009, Oktober 24). Mari Ke Siberut Utara. [Online]. Available: http://www.puailiggoubat.com

[3] NASA Surface Meteorology and Solar Energy Data. (2013, Agustus 11). Monthly Averaged Insolation Incident On A Horizontal Surface. [Online]. Available: http://www.data.nasa.gov/surfacemeteorology-and-solar-energy

[4] The HOMER 2 Software. (2013, April 8). HOMER 2 Version 2.81 [Online]. Available: http://www.homerenergy.com

[5] Rosyid, O. A., "Pembangkit Listrik Tenaga Surya Hibrida Untuk Listrik Pedesaan di Indonesia", Jurnal Material dan Energi Indonesia, vol. 1, no. 1, hal. 31-38, 2011.

[6] Kunaifi, "Program HOMER Untuk Studi Kelayakan Pembangkit Listrik Hibrida Di Propinsi Riau", Seminar Nasional Informatika, FTI UPN "Veteran" Yogyakarta, 2010, hal. 18-27.

[7] Nayar, C. V. dkk., "Novel Wind/Diesel/Battery Hybrid Energy System", Solar Energy, vol. 51, no.1, hal. 65-78, 1993.

[8] Sopian, K. dan Othman, M. Y., "Performance of a Photovoltaic Diesel Hybrid System in Malaysia", Isesco Science and Technology Vision, vol.1, hal. 37-39, May 2005.

[9] Quaschning, Volker, "Photovoltaics", Understanding Renewable Energy Systems, London, Sterling, VA: Earthscan, 2005, chapter 4, hal. 115-172.

[10] Sitompul, Rislima, Manual Pelatihan Teknologi Energi Terbarukan yang Tepat Untuk Aplikasi di Masyarakat Pedesaan. Jakarta: PNPM Support Facility (PSF), 2011, hal.45-75.

[11] Handbook for Solar Photovoltaic (PV) Systems, Grenzone Pte Ltd, Phoenix Solar Pte Ltd, Singapore Polytechnic, Solar Energy, Research Institute of Singapore (SERIS), SP PowerGrid, Urban Redevelopment Authority, Singapore, ISBN: 978-981-08-4462-2, hal. 4-15. 
[12] Strong, Steven J., The Solar Electric House, A Design Manual for Home-Scale Photovoltaic Power Systems, Pennsylvania : Rodale Press, 1987.

[13] Foster, Robert, dkk., Solar Energy : Renewable Energy and The Environment. Boca Raton, FL : CRC Press, Taylor \& Francis Group, 2010.

[14] (2013, Maret 15). [Online]. Available: http://www.cmacpower.co.za

[15] (2013, Maret 15). [Online]. Available: http://www.solarsuryaindonesia.com

[16] Lambert, Tom, $d k k$., "Micropower System Modeling with HOMER", Integration of Alternative Sources of Energy, United States of America : John Wiley \& Sons Inc., April 2006, chapter 15, pp. 379-418.

[17] National Renewable Energy Laboratory, USA. (2012, November 28). Homer Energy Modelling Software for Hybrid Renewable Energy System [Online]. Available: http://www.homerenergy.com

[18] Diesel Generator Set Caterpillar. (2013, Januari 20). Olympian ${ }^{\mathrm{TM}}$ GEP16SP-2 220$240 \mathrm{~V} 50 \mathrm{~Hz} 15 \mathrm{~kW}$. [Online]. Available: http://www.CAT-ElectricPower.com

[19] Sunny International Power Corp. (2013, Maret 11). Monocrystalline Solar Panel Sunny Power 100 WP. [Online]. Available: http://www.sunnypowersolar.com

[20] Surrette Battery Company Limited, Canada. (2013, Maret 12). Rolls Surrette Battery 4 Volt 1900 AH 4KS25PS. [Online]. Available: http://www.rollsbattery.com

[21] SMA America, LLC. 2010. (2013, Maret 15). Bidirectional Inverter Sunny Island 6048-US. [Online]. Available: http://www.SMA-America.com

\section{Biodata Penulis}

Dewi Purnama Sari, lahir di Padang tanggal 5 Oktober. Pendidikan S1 di Jurusan Teknik Elektro Universitas Bung Hatta Padang pada tahun 1999. Pendidikan S2 di Jurusan Teknik Elektro Universitas Andalas Padang dengan Program Studi Teknik Energi Elektrik pada tahun 2011. 